http://jmscr.igmpublication.org/home/ ISSN (e)-2347-176x ISSN (p) 2455-0450

crossref DOI: https://dx.doi.org/10.18535/jmscr/v7i9.65

Journal Of Medical Science And Clinical Research

IGM Publication

An Official Publication of IGM Publication

\title{
Association of Microalbuminuria with IHD in Asymptomatic Type-2 Diabetes Mellitus Patients
}

\author{
Authors \\ Dr Sukh Chain ${ }^{1}$, Dr Mansa Ram Saran ${ }^{2 *}$, Dr Rajendra Kumar Kasana ${ }^{3}$, \\ Dr Vikash Kumar Agarwal ${ }^{4}$ \\ ${ }^{1,4}$ Junior Specialist, ${ }^{2}$ Principal Specialist, ${ }^{3}$ Assistant Professor \\ ${ }^{1,2,4}$ Department of General Medicine, Govt. Shri Kalyan Hospital, Sikar, Rajasthan, India. \\ ${ }^{3}$ Department of General Medicine, S.M.S. Medical College, Jaipur, Rajasthan, India \\ *Corresponding Author \\ Dr Mansa Ram Saran
}

\begin{abstract}
Introduction: Recent studies have shown that presence of microalbuminuria in diabetic patients is associated with increased incidence of silent myocardial ischemia or asymptomatic coronary artery disease, which can be a cause of increased mortality due to cardiovascular diseases. Present study was conducted to see the association of microalbuminuria with IHD in asymptomatic type-2 diabetes mellitus patients.
\end{abstract}

Material and Methods: It was a comparative, analytic type of observational study carried out atDepartment of Medicine, S.M.S. Medical College, Jaipur, Rajasthan (India) from October 2011 to September 2012. After approval from institutional ethics committee 47 normoalbuminuric and 47 microalbuminuric asymptomatic type-2 diabetes mellitus patients were taken. Patients were asked for duration and symptoms of diabetes mellitus. Peripheral pulses were palpated to detect peripheral artery disease, foot examination was done to detect any ulcer, trophic changes or signs of ischaemia. Systolic and diastolic blood pressures, weight, BMI, waist circumference and waist-hip ratio were measured, Biochemical tests like fasting and post-prandial blood sugar, serum insulin, HbAlC, total lipid profile and urine examination were done. Treadmill test and transthoracic echocardiography was done. The data were statistically analysed using chi square test and unpaired 't' test. P-value $<0.05$ was considered as statistically significant.

Results: No significant difference was observed in age, sex, weight, BMI, waist circumference, waist-hip ratio, history of smoking and all biochemical parameters except HDL and LDL cholesterol in both the groups. Duration of type-2 diabetes mellitus, mean systolic and diastolic blood pressures were significantly associated with microalbuminuria in asymptomatic type-2 diabetes mellitus patients. Overall, 34.04\% patients with microalbuminuria had evidence of silent myocardial ischemia (SMI) as compared to $6.38 \%$ normoalbuminuric subjects which was statistically significant $(P<0.05)$. Ejection fraction was comparable in both the groups.

Conclusion: Present study showed that there was increased occurrence of silent myocardial ischemia (SMI) in asymptomatic type-2 diabetes mellitus patients who had microalbuminuria as compared to those who had normoalbuminuria.

Keywords: Type-2 diabetes mellitus, Asymptomatic, Microalbuminuria, Normoalbuminuria, Ischemic heart disease. 


\section{Introduction}

Type-2 diabetes mellitus (T2DM) is a heterogeneous group of disorders characterized by variable degrees of insulin resistance, impaired insulin secretion and increased glucose production. The prevalence of diabetes is rising worldwide with 285 million estimated cases in 2010 and expected to raise 366 million cases in 2030. Among these type-2 diabetes mellitus involves more than $90 \%$ of the cases of the disease. ${ }^{1}$ India leads the world with largest number of diabetic subjects earning the dubious distinction of being termed the "diabetes capital of the world". According to the Diabetes Atlas 2006 published by the International Diabetes Federation, the number of people with diabetes in India are around 40.9 million and expected to rise to 69.9 million by 2025 . $^{2}$

In recent years studies have shown that in diabetic patients, the presence of microalbuminuria (MA) is associated with increased incidence of silent myocardial ischemia (SMI). It appears that microalbuminuria in type-2 diabetic patients is an indicator of vascular damage in general, and represents an independent risk factor for increased morbidity and mortality due to coronary artery disease (CAD). ${ }^{3}$ Coronary artery disease is the leading cause of death in patients with type-2 diabetes mellitus and is often asymptomatic or 'silent'. The cardiovascular mortality is increased two-fold in men and four-fold in women in the presence of T2DM, thus emphasizing the potential value of identifying high-risk asymptomatic individuals with diabetes. ${ }^{4,5}$

Silent myocardial ischemia (SMI) can be detected by using treadmill exercise testing. SMI has been defined as exercise-induced ST-segment depression in the absence of CAD symptoms. Prevalence of microalbuminuria (MA) is observed in $15 \%$ to $25.9 \%$ patients of type-2diabetes mellitus and is associated with a doubling of the risk of early death, mainly from CAD. The presence of underlying silent myocardial ischemia and microalbuminuria are significantly related to future CAD events in asymptomatic patients with type-2 diabetes mellitus, therefore SMI and MA could be of predictive value in riskstratification., The purpose of our study was to find out the association of presence of microalbuminuria in asymptomatictype-2 diabetes mellitus patients with development of silent myocardial ischemia.

\section{Material and Methods}

It was a hospital based, comparative, analytic study, carried out in Department of Medicine, S.M.S. Medical College, Jaipur (Rajasthan) from October 2011 to September 2012. Prior approval from institutional ethics committee was obtained. Total94 type- 2 diabetes mellitus patients between age group 40-60 years and asymptomatic for ischemic heart disease (47 normoalbuminuric and 47 microalbuminuric) were recruited in the study after taking informed written consent. Patients with urinary tract infection, haematuria, heart failure, febrile illness, severe hyperglycaemia, severe hypertension, pregnant women, seriously ill patients or on life supporting measures, known case of CAD, any renal disease due to causes other than type- 2 diabetes mellitus, with abnormal resting ECG and contraindications to exercise stress test were excluded from the study.

Selected patients were evaluated clinically by history taking including age, sex, duration of diabetes and clinical examination including general physical examination, assessment of vitals and systemic examination. Patients were asked for symptoms of diabetic complications such as visual disturbances, diplopia, dyspnoea, chest pain, orthopnoea, numbness, paraesthesia, weakness in limbs, pedal swelling, intermittent claudication and foot ulcers. Patients were thoroughly evaluated for pallor, edema, presence of acanthosis nigricans, xanthoma and xanthelasma. Blood pressure was measured in right arm in supine position. Those with systolic blood pressure $\geq 140 \mathrm{mmHg}$ or diastolic blood pressure $\geq 90 \mathrm{mmHg}$ or on antihypertensive medications were considered as hypertensive. All peripheral pulses were palpated to detect peripheral artery disease. Foot examination was thoroughly done to 
detect any ulcer, trophic changes or signs of ischaemia.

Anthropometric parameters like weight, height, BMI, waist circumference, hip circumference, waist-hip ratio (WHR) were measured. Height was measured to the nearest $0.5 \mathrm{~cm}$ without shoes. Each participant stood in such a way so that the Frankfort plane (a line connecting the superior border of the external auditory meatus with the infraorbital rim) was horizontal (i.e. parallel to the floor). Weight was measured after removal of shoes and was recorded to the nearest $0.1 \mathrm{~kg}$. BMI was calculated as weight $(\mathrm{kg}) /$ height $(\mathrm{m})^{2}$. Those with a BMI of $25.0-29.99 \mathrm{~kg} / \mathrm{m}^{2}$ were classified as overweight, whilst those with a BMI $\geq 30.0 \mathrm{~kg} /$ $\mathrm{m}^{2}$ were classified as obese.BMI between 18.50 $24.99 \mathrm{~kg} / \mathrm{m}^{2}$ being considered as normal. While those with BMI $<18.5 \mathrm{~kg} / \mathrm{m}^{2}$ are considered undernourished. Waist circumference was measured using a measuring tape, with measurements made halfway between the lower border of the ribs and the iliac crest in a horizontal plane. Hip circumference was measured at the widest point over the buttocks. For each of waist and hip circumference, two measurements to the nearest $0.5 \mathrm{~cm}$ were recorded. If the variation between the measurements was greater than $2 \mathrm{~cm}$, a third measurement was taken. The mean of the two closest measurements was calculated. Men with a waist circumference 94-101.9 cm and women with a waist circumference $80-87.9 \mathrm{~cm}$ were classified as overweight, whilst men with a waist circumference $\geq 102.0 \mathrm{~cm}$ and women with a waist circumference $\geq 88.0 \mathrm{~cm}$ were classified as obese WHR was obtained by dividing the mean waist circumference by the mean hipcircumference. Men with a WHR 0.90-0.99 and women with a WHR $0.80-0.84$ were classified as overweight, whilst men with a WHR $\geq 1.00$ and women with a WHR $\geq 0.85$ were classified as obese.

After overnight fasting for 10-12 hours blood of the patients was sent for investigations such as fasting blood sugar, serum insulin, HbA1C and total lipid profile. Post-prandial blood sugar
(PPBS) was measured 2 hours after meal. Plasma glucose was measured with glucose oxidase technique on automated auto analyzer. Glycated haemoglobin was measured by chromatography analyzer and a value of less than $7 \%$ was taken to indicate good glycaemic control. Total lipid estimated by sulfo-phosphovainilline assay- a colorimetry-based method. Total cholesterol was estimated by an enzymatic method using cholesterol esterase cholesterol oxidase and peroxidise. HDL cholesterol was estimated by a reagent-based assay using automated clinical chemistry analyzer. LDL cholesterol was measured using an enzymatic colorimetric technique. Triglyceride was estimated by GOD/POD method. Serum creatinine was measured by a test which is based on the peroxidase like activity of a copper creatinine complex that catalyses the reaction of disopropylbenzene dihydroperoxide and tetra methyl benzidine. The resulting colour range from orange through green and blue.

Urine routine examination from fasting urine sample was done to measure microalbuminuria for every patient. Albumin is normally present in urine at concentrations of less than $20 \mathrm{mg} / \mathrm{L}$. Microalbuminuria is indicated with results of 20 $200 \mathrm{mg} / \mathrm{L}$. Creatinine is normally present in urine at concentration of $10-300 \mathrm{mg} / \mathrm{dl}(0.9-$ $26.5 \mathrm{mmol} / \mathrm{L}$ ).

Albumin is normally present in urine at concentration of less than $30 \mathrm{mg}$ albumin/gm creatinine (3.4mg albumin $/ \mathrm{mmol}$ creatinine). Microalbuminuria is indicated at a ratio of 30 $300 \mathrm{mg} / \mathrm{gm}(3.4-33.9 \mathrm{mg} / \mathrm{mmol}$ ) (Abnormal) and clinical albuminuria at a ratio of $>300 \mathrm{mg} / \mathrm{gm}$ (>33.9mg/mmol) (highly abnormal). Patients with high abnormal values i.e. macroalbuminuria were excluded from study. For microalbuminuria clinitek 100 test was used. This test is based on dye binding using a high affinity sulfonaphthalin dye. At a constant $\mathrm{pH}$, development of blue colour is due to albumin.

Patients were subjected to exercise treadmill testing using Bruceprotocol. Twelve lead ECG 
and blood pressure measurement were done at rest, before starting test. Heart rate and blood pressure were measured at the end of each stage and every 2 minutes during the recovery phase. Hypotension was considered if there was a decrease in systolic blood pressure $10 \mathrm{~mm}$ of $\mathrm{Hg}$ or BP falls below the resting value. The interruption criteria used was horizontal or down sloping ST segment depression $\geq 1 \mathrm{~mm}, \quad$ ST elevation $\geq 1 \mathrm{~mm}$ compared to baseline ECG, $\geq 10 \%$ decrease in systolic blood pressure, no increase in heart rate or presence of bradycardia, blood pressure above 250/150mm $\mathrm{Hg}$, severe angina, development of severe arrhythmia, attaining target heart rate and being too tired to sustain the test. Exercise test was considered positive in case of horizontal or down sloping ST segment depression $\geq 1 \mathrm{~mm}$, development of angina during the test, and $\geq 10 \%$ decrease in systolic blood pressure.

Transthoracic echocardiography was done in the left lateraldecubitus position by the same cardiologist to see LV function and any regional wall motion abnormality or any abnormality suggesting ischemic heart disease.

Data thus collected were entered in Microsoft Excel 2010worksheets in the form of master chart. Qualitative data were expressed in the form of percentage and proportions. Quantitative data were expressed in the form of means and standard deviations. Chi Square test and unpaired ' $t$ ' test were used to see association. A p-value $<0.05$ was considered statistically significant.

\section{Results}

The patients of type-2 diabetes mellitus, who were free from symptoms of ischemic heart disease like chest pain, dyspnoea on exertion, fatigue and orthopnoea were considered asymptomatic. 47 such asymptomatic patients of type- 2 diabetes mellitus without microalbuminuria were taken as group-A and similar number of asymptomatic patients of type-2 diabetes mellitus with microalbuminuria were taken as group-B. Patients of both sexes from various medical wards and OPD were taken for study.

Majority of patients in group-A were in age group of 56-60 years ( $36.17 \%)$, followed by $51-55$ years $(27.65 \%)$, whereas in group-B majority of patients were in age group of 51-55 years (40.42\%), followed by $56-60$ years $(27.65 \%)$. Males were $61.7 \%$ in group-A while $53.19 \%$ in group-B. Majority of subjects were non-smokers in both the groups, only $14.89 \%$ subjects in group-A and $17.02 \%$ subjects in group-B were smokers. Overweight and obesity were more common in microalbuminuria group (group-B) as compared to normoalbuminuria group (group-A) according to BMI, waist circumference and waist-hip ratio criteria (Table-1).

Age, sex, weight, obesity criteria like, BMI, waist circumference and waist-hip ratio and personal history of smoking were not significantly different $(\mathrm{P}>0.05)$ in both the groups suggesting good randomization and comparability (Table-1 \&2).

In the present study $29.78 \%$ subjects were hypertensive in group-B and $25.53 \%$ in group-A and this difference was not significant $(\mathrm{P}>0.05$, Table-3) but mean systolic and mean diastolic blood pressures in both groups were significantly different $(\mathrm{P}<0.05$, Table-2). All biochemical parameters (fasting blood sugar, post-prandial blood sugar, serum insulin, HbA1C, total lipids, total cholesterol and triglycerides) did not shown the significant difference except HDL and LDL. Left ventricular ejection fraction (Table-2) and left ventricular diastolic dysfunction (Table-3) were also not significantly different in both the groups.

The present study revealed that duration of type- 2 diabetes mellitus was significantly associated with microalbuminuria. Silent myocardial ischemic was significantly high (34.04\%) in microalbuminuria group in comparison to normoalbuminuria group $(6.38 \%)(\mathrm{P}<0.05$, Table3 ). Chest pain was developed in $93.75 \%$ patients of SMI during treadmill test in microalbuminuria group while it was observed only in $66.67 \%$ patients of SMI in normoalbuminuria group (Table-4). 
Table-1: Distribution of subjects according to demographic and personal profile $(\mathrm{N}=94)$

\begin{tabular}{|c|c|c|c|}
\hline Parameter & $\begin{array}{c}\text { Group-A } \\
\text { (Normoalbuminuri } \\
\text { a) } \\
\text { n }(\%) \\
\end{array}$ & $\begin{array}{c}\text { Group-B } \\
\text { (Microalbuminur } \\
\text { ia) } \\
\text { n }(\%) \\
\end{array}$ & P-value ${ }^{*}$ \\
\hline \multicolumn{4}{|l|}{ Age: } \\
\hline $40-45$ & $9(19.14)$ & $6(12.76)$ & \multirow{4}{*}{$0.695^{*}$} \\
\hline $46-50$ & $8(17.02)$ & $9(19.14)$ & \\
\hline $51-55$ & $13(27.65)$ & $19(40.42)$ & \\
\hline $56-60$ & $17(36.17)$ & $13(27.65)$ & \\
\hline \multicolumn{4}{|l|}{ Gender: } \\
\hline Male & $29(61.70)$ & $25(53.19)$ & \multirow{2}{*}{$0.531^{\#}$} \\
\hline Female & $18(38.29)$ & $22(46.80)$ & \\
\hline \multicolumn{4}{|l|}{ Smoking: } \\
\hline Yes & $7(14.89)$ & $8(17.02)$ & \multirow{2}{*}{1.000} \\
\hline No & $40(85.10)$ & $39(82.97)$ & \\
\hline \multicolumn{4}{|l|}{ BMI $\left(\mathrm{kg} / \mathrm{m}^{2}\right):$} \\
\hline $\begin{array}{lll}\text { Normal } & (18.50 \quad- \\
24.99) & & \\
\end{array}$ & $17(36.17)$ & $8(17.02)$ & \multirow{3}{*}{0.109} \\
\hline $\begin{array}{l}\text { Overweight (25.0- } \\
29.99)\end{array}$ & $5(10.63)$ & $7(14.89)$ & \\
\hline Obese $(\geq 30.0)$ & $25(53.19)$ & $32(68.09)$ & \\
\hline \multicolumn{4}{|c|}{ Waist Circumference: } \\
\hline $\begin{array}{l}\text { Normal } \\
(\mathrm{m}=<94 \mathrm{~cm}, \quad \mathrm{f}= \\
<80 \mathrm{~cm})\end{array}$ & $17(36.17)$ & $7(14.89)$ & \multirow{3}{*}{0.059} \\
\hline $\begin{array}{l}\text { Over weight } \\
(\mathrm{m}=94-101.99 \mathrm{~cm}, \\
\mathrm{f}=80-87.99 \mathrm{~cm})\end{array}$ & $6(12.76)$ & $7(14.89)$ & \\
\hline $\begin{array}{l}\text { Obese } \\
(\mathrm{m}=\geq 102 \mathrm{~cm}, \quad \mathrm{f}= \\
\geq 88 \mathrm{~cm})\end{array}$ & $24(51.06)$ & $33(70.21)$ & \\
\hline \multicolumn{4}{|l|}{ Waist Hip Ratio: } \\
\hline $\begin{array}{l}\begin{array}{l}\text { Normal } \\
(\mathrm{m}=\end{array}<0.90, \quad \mathrm{f}= \\
<.80)\end{array}$ & $16(34.04)$ & $7(14.89)$ & \multirow{3}{*}{0.097} \\
\hline $\begin{array}{l}\text { Over weight } \\
(\mathrm{m}=0.90-0.99, \mathrm{f}= \\
0.80-0.84)\end{array}$ & $6(12.76)$ & $8(17.02)$ & \\
\hline $\begin{array}{l}\text { Obese } \\
(\mathrm{m}=\geq 1.00, \quad \mathrm{f}= \\
\geq 0.85)\end{array}$ & $25(53.19)$ & $32(68.09)$ & \\
\hline
\end{tabular}

*Chi square test

Table-2: Comparative analysis of various parameters in both groups ( $\mathrm{N}=47$ in each group)

\begin{tabular}{|l|c|c|c|}
\hline Parameter & $\begin{array}{c}\text { Group-A } \\
\text { (Normoalbuminuria) } \\
\text { (Mean } \pm \text { SD) }\end{array}$ & $\begin{array}{c}\text { Group-B } \\
\text { (Microalbuminuria) } \\
\text { (Mean } \pm \text { SD) }\end{array}$ & $\begin{array}{c}\text { P- } \\
\text { value* }\end{array}$ \\
\hline Weight (in kg) & $73.39 \pm 11.55$ & $76.28 \pm 10.64$ & 0.210 \\
\hline BMI(kg /mt ${ }^{2}$ ) & $27.91 \pm 4.53$ & $29.15 \pm 3.51$ & 0.141 \\
\hline $\begin{array}{l}\text { Duration (in } \\
\text { years) }\end{array}$ & $3.76 \pm 2.76$ & $5.48 \pm 3.61$ & 0.011 \\
\hline SBP(mm of Hg) & $122.34 \pm 10.33$ & $132.08 \pm 13.87$ & $<0.01$ \\
\hline DBP(mm of Hg) & $80.42 \pm 5.86$ & $84.85 \pm 6.2$ & $<0.01$ \\
\hline FBS & $126.08 \pm 27.19$ & $130.28 \pm 23.26$ & 0.423 \\
\hline PPBS & $187.32 \pm 35.60$ & $198.76 \pm 26.67$ & 0.081 \\
\hline Serum insulin & $10.11 \pm 4.34$ & $10.73 \pm 4.22$ & 0.484 \\
\hline HbA1C & $7.35 \pm 1.47$ & $8.11 \pm 1.58$ & 0.018 \\
\hline Total Lipid & $550.38 \pm 99.34$ & $558.23 \pm 116.51$ & 0.726 \\
\hline $\begin{array}{l}\text { Total } \\
\text { Cholesterol }\end{array}$ & $167.94 \pm 37.88$ & $181.51 \pm 41.56$ & 0.101 \\
\hline HDL & $44.66 \pm 6.17$ & $40.96 \pm 4.57$ & 0.001 \\
\hline LDL & $95.83 \pm 33.05$ & $111.28 \pm 37.04$ & 0.036 \\
\hline Triglycerides & $137.15 \pm 47.95$ & $147.02 \pm 42.70$ & 0.295 \\
\hline LVEF(\%) & $61.17 \pm 3.60$ & $60.32 \pm 4.66$ & 0.325 \\
\hline "Unpaired 't' test & & &
\end{tabular}

Table-3: Association of various parameters with microalbuminuria in asymptomatic T2DM patients

\begin{tabular}{|c|c|c|c|}
\hline Parameter & $\begin{array}{c}\text { Group-A } \\
\text { (Normoalbuminuria) } \\
\mathbf{n}(\%)\end{array}$ & $\begin{array}{c}\text { Group-B } \\
\text { (Microalbuminuria) } \\
\text { n }(\%)\end{array}$ & $\begin{array}{c}\text { P- } \\
\text { value }^{*}\end{array}$ \\
\hline \multicolumn{4}{|c|}{ Duration of T2DM: } \\
\hline $0-5$ Years & $38(80.85)$ & $26(55.31)$ & \multirow{3}{*}{0.029} \\
\hline 6-10 Years & $7(14.89)$ & $16(34.04)$ & \\
\hline 11-15 Years & $2(4.25)$ & $5(10.63)$ & \\
\hline \multicolumn{4}{|c|}{ Hypertension: } \\
\hline Yes & $12(25.53)$ & $14(29.78)$ & \multirow{2}{*}{0.818} \\
\hline No & $35(74.46)$ & $33(70.21)$ & \\
\hline \multicolumn{4}{|c|}{ Left ventricular diastolic dysfunction: } \\
\hline Yes & $3(6.38)$ & $5(10.64)$ & \multirow{2}{*}{0.712} \\
\hline No & $44(93.62)$ & $42(89.36)$ & \\
\hline \multicolumn{4}{|c|}{ Silent myocardial ischemia: } \\
\hline Yes & $3(6.38)$ & $16(34.04)$ & \multirow{2}{*}{0.002} \\
\hline No & $44(93.62)$ & $31(65.96)$ & \\
\hline
\end{tabular}

*Chi square test

Table-4: Distribution of symptoms during treadmill test in patients with SMI

\begin{tabular}{|c|c|c|c|c|}
\hline \multirow[t]{2}{*}{ Symptoms } & \multicolumn{2}{|c|}{$\begin{array}{c}\text { Group-A } \\
\text { (Normoalbuminuria) }\end{array}$} & \multicolumn{2}{|c|}{$\begin{array}{c}\text { Group-B } \\
\text { (Microalbuminuria) }\end{array}$} \\
\hline & $\mathbf{N}=3$ & $\%$ & $\mathrm{~N}=16$ & $\%$ \\
\hline Chest pain & 2 & 66.67 & 15 & 93.75 \\
\hline Dyspnoea & 3 & 100 & 9 & 56.25 \\
\hline Fatigue & 1 & 33.33 & 4 & 25 \\
\hline Dizziness & 0 & 0 & 3 & 18.75 \\
\hline
\end{tabular}

\section{Discussion}

It was observed in the present study that microalbuminuric (MA) patients had higher values of BMI than normoalbuminuric (NA)diabetic patients $\left(29.15 \pm 3.51 \mathrm{~kg} / \mathrm{m}^{2} \mathrm{MA}\right.$ and $27.91 \pm 4.53 \mathrm{~kg} / \mathrm{m}^{2}$ in NA) but the difference was not significant $(\mathrm{P}>0.05)$. Similar results were observed by Hussein and Strak $^{7}$ (BMI $27.5 \pm 6.3$ $\mathrm{kg} / \mathrm{m}^{2}$ in MA, $27 \pm 5.18 \mathrm{~kg} / \mathrm{m}^{2} \mathrm{NA}$ ) while contrary results were observed by Rutter et $\mathrm{al}^{5}(30 \pm 4.8$ $\mathrm{kg} / \mathrm{m}^{2}$ vs. $27.1 \pm 4.8 \mathrm{~kg} / \mathrm{m}^{2}$ respectively, $\mathrm{P}<0.05$ ).

The present study revealed that about $55.31 \%$ microalbuminuric patients and $80.85 \%$ normoalbuminuric patients had diabetes mellitus from 0-5 years. A significant difference was seen between the two groups in regard to duration of type-2 DM $(5.48 \pm 3.61$ years in MA and $3.76 \pm$ 2.76 years in NA, $\mathrm{P}<0.05)$. Hussein and $\mathrm{Strak}^{7}$, Yildirimturk et $\mathrm{al}^{8}$ and Rani et $\mathrm{al}^{9}$ also found similar results.

Hypertension (29.78\% vs. $25.53 \%)$ and smoking habit $(17.02 \%$ vs. $14.89 \%)$ were more in microalbuminuric group than normoalbuminuric group, but this difference was statistically not 
significant $\quad(\mathrm{P}>0.05)$. Similar results were observed by Hussein and Strak $^{7}$ andYildirimturk et $\mathrm{al}^{8}$ in their studies. Although significant difference was seen in both groups with regard to mean systolic BP $(132.08 \pm 13.87 \mathrm{~mm} \mathrm{Hg}$ vs.122.34 \pm $10.33 \mathrm{~mm} \mathrm{Hg}$ respectively, $\mathrm{P}<0.05)$ and mean diastolic BP $(84.85 \pm 6.2 \mathrm{~mm} \mathrm{Hg}$ vs. $80.42 \pm 5.86$ $\mathrm{mm} \mathrm{Hg}$ respectively, $\mathrm{P}<0.05)$. Rani et $\mathrm{al}^{9}$ also observed a significant difference in microalbuminuric and normoalbuminuric subjects with regard to systolic BP and diastolic BP $(\mathrm{P}<0.05)$ while Rutter et $\mathrm{al}^{5}$ observed in their study that systolic BP was significantly higher in microalbuminuric subjects than normoalbuminuric $(\mathrm{P}<0.05)$. Hussein and $\mathrm{Strak}^{7}$ showed that diastolic BP was significantly higher in microalbuminuric patients than normoalbuminuric $(\mathrm{P}<0.05)$. Yildirimturk et $\mathrm{al}^{8}$ showed no significant difference between microalbuminuric and normoalbuminuric type-2 diabetic subjects with regard to systolic and diastolic BP $(\mathrm{P}>0.05)$.

In present study patients with microalbuminuria had higher values of fasting blood sugar as compared to their normoalbuminuric counterparts $(146.15 \pm 30.20 \mathrm{mg} / \mathrm{dl}$ vs. $126.08 \pm 27.19 \mathrm{mg} / \mathrm{dl}$ respectively) and the difference between two groups was significant $(\mathrm{P}<0.001)$. A statistically significant difference with regard to post-prandial blood sugar was also observed between microalbuminuric and normoalbuminuric type-2 diabetic subjects $(208 \pm 36.18 \mathrm{mg} / \mathrm{dl}$ vs. $187.32 \pm$ $35.60 \mathrm{mg} / \mathrm{dl}$ respectively, $\mathrm{P}<0.001)$. Earlier, Rutter et $\mathrm{al}^{5}(10.6 \pm 3.9 \mathrm{mmol} / \mathrm{l}$ in MA, $9.4 \pm$ $3.6 \mathrm{mmol} / 1$ in NA, P>0.05), Hussein and $\mathrm{Strak}^{7}$ $(152.7 \pm 26 \mathrm{mg} / \mathrm{dl}$ in MA, $131 \pm 19.5 \mathrm{mg} / \mathrm{dl}$ in NA, $\mathrm{P}<0.05)$ and Mattock et $\mathrm{al}^{10}(10.5 \mathrm{mmol} / \mathrm{l}$ in MA, $8.89 \mathrm{mmol} / \mathrm{l}$ in NA, $\mathrm{P}<0.05)$ found higher values of fasting plasma glucose in microalbuminuric type-2 diabetic subjects as compared to normoalbuminuric type-2 diabetic subjects in their studies. Yildirimturk et $\mathrm{al}^{8}$ observed low values of fasting plasma glucose in microalbuminuric type-2 diabetic subjects (141.3 $\pm 29.5 \mathrm{mg} / \mathrm{dl}$ ) as compared to normoalbuminuric type- 2 diabetic counterparts $(142 \pm 40.6 \mathrm{mg} / \mathrm{dl})$ in their study, but the difference was not significant $(\mathrm{P}>0.05)$.

No significant difference with regard to serum insulin was observed in microalbuminuric and normoalbuminuric type- 2 diabetic subjects in the present study $(10.73 \pm 4.22$ vs. $10.11 \pm 4.34$ respectively, $\quad \mathrm{P}>0.05)$, although significantly higher values $(\mathrm{P}<0.05)$ of glycated haemoglobin (HbA1c) were seen in microalbuminuric type-2 diabetic subjects $(8.11 \pm 1.58 \mathrm{gm} \%)$ as compared to normoalbuminuric type-2 diabetic subjects $(7.35 \pm 1.47 \mathrm{gm} \%)$. Similarly, Rutter et $\mathrm{al}^{5}(8.7 \pm$ $1.6 \mathrm{gm} \%$ in MA, $7.9 \pm 1.3 \mathrm{gm} \%$ in NA), Yildirimturk et $\mathrm{al}^{8}(7.5 \pm 2.0 \mathrm{gm} \%$ vs. $6.9 \pm 1.4$ gm\% respectively), Rani et al ${ }^{9}(9.0 \pm 2.3$ gm\% vs. $8.0 \pm 2.1$ gm\% respectively) and Mattock et $\mathrm{al}^{10}(9.7 \mathrm{gm} \%$ vs. $8.3 \mathrm{gm} \%$ respectively) were also observed the higher values of glycated haemoglobin (HbA1c) in microalbuminuric group as compared to normoalbuminuric group. The difference between microalbuminuric type-2 diabetic subjects and normoalbuminuric type-2 diabetic subjects were significant $(\mathrm{P}<0.05)$ in studies by Rutter et $\mathrm{al}^{5}$, Rani et $\mathrm{al}^{9}$ and Mattock et $\mathrm{al}^{10}$ while it was not significant $(\mathrm{P}>0.05)$ in study by Yildirimturk et $\mathrm{al}^{8}$.

Present study suggested that total lipids were higher in microalbuminuric group compared with normoalbuminuric group $(550.38 \pm 99.34 \mathrm{mg} / \mathrm{dl}$ in NA vs. $558.23 \pm 116.51 \mathrm{mg} / \mathrm{dl}$ in MA), but the difference was statistically not significant $(\mathrm{P}>0.05)$. The values of total cholesterol were also higher in microalbuminuric group (181.51 \pm 41.56 $\mathrm{mg} / \mathrm{dl}$ ) as compared to normoalbuminuric group $(167.94 \pm 37.88 \mathrm{mg} / \mathrm{dl})$ and again the difference was statistically not significant $(\mathrm{P}>0.05)$. Similar results were observed by previous authors like, Rutter et $\mathrm{al}^{5}$ (5.6 mmol/l in MA, $5.5 \mathrm{mmol} / \mathrm{l}$ in $\mathrm{NA})$, Hussein and $\mathrm{Strak}^{7}(205 \pm 40.8 \mathrm{mg} / \mathrm{dl}$ in MA, $181.4 \pm 28.7 \mathrm{mg} / \mathrm{dl}$ in NA) Yildirimturk et $\mathrm{al}^{8}$ $(207.7 \pm 44.6 \mathrm{mg} / \mathrm{dl}$ in MA, $194.7 \pm 31.6 \mathrm{mg} / \mathrm{dl}$ in $\mathrm{NA})$ and Mattock et $\mathrm{al}^{10}(6.74 \pm 0.26 \mathrm{mmol} / \mathrm{dl}$ in MA, $6.05 \pm 0.12 \mathrm{mmol} / \mathrm{dl}$ in NA) in their studies where they observed the higher values of total cholesterol in microalbuminuric group as 
compared to normoalbuminuric group. The difference between microalbuminuric type-2 diabetic subjects and normoalbuminuric type-2 diabetic subjects were significant $(\mathrm{P}<0.05)$ in studies by Hussein and $\operatorname{Strak}^{7}$ and Mattock et al ${ }^{10}$ while it was not significant $(\mathrm{P}>0.05)$ in studies by Rutter et $\mathrm{al}^{5}$ and Yildirimturk et $\mathrm{al}^{8}$.

The values of LDL cholesterol in present study were also significantly higher in microalbuminuric group as compared to normoalbuminuric group $(111.28 \pm 37.4 \mathrm{mg} / \mathrm{dl}$ vs. $95.83 \pm 33.05 \mathrm{mg} / \mathrm{dl}$ respectively, $\mathrm{P}<0.05)$. Similar results were found by Yildirimturk et $\mathrm{al}^{8}(125.6 \pm 32.0$ vs. $113.5 \pm 27.5$ respectively)in their study but the difference was not significant $(\mathrm{P}>0.05)$. The HDL was significantly low in microalbuminuric group as compared to normoalbuminuric group (40.96 \pm 4.57 vs. $44.66 \pm 6.17$ respectively) in this study. This difference was statistically significant $(\mathrm{P}<0.01)$. Rutter et $\mathrm{al}^{5}(1.0 \pm 0.3 \mathrm{mmol} / \mathrm{l}$ in $\mathrm{MA}$, $1.2 \pm 0.4 \mathrm{mmol} / \mathrm{l}$ in NA), Hussein and $\operatorname{Strak}^{7}(47.6$ $\pm 13 \mathrm{mg} / \mathrm{dl}$ vs. $48.6 \pm 14.7 \mathrm{mg} / \mathrm{dl}$ respectively) and Rani et $\mathrm{al}^{9}(38.8 \pm 9.3 \mathrm{mg} / \mathrm{dl}$ vs. $39.2 \pm 10.2 \mathrm{mg} / \mathrm{dl}$ respectively) also seen the same results in their studies, but the difference was statistically not significant $(\mathrm{P}>0.05)$ in these studies. The values of triglycerides in present study were also higher in microalbuminuric group as compared to normoalbuminuric group $(147.02 \pm 42.70 \mathrm{mg} / \mathrm{dl}$ vs. $137.15 \pm 47.95 \mathrm{mg} / \mathrm{dl}$ respectively) but the difference was not significant $(\mathrm{P}>0.05)$. Earlier, Rutter et $\mathrm{al}^{5}$, Yildirimturk et $\mathrm{al}^{8}(145 \pm 59.6 \mathrm{mg} / \mathrm{dl}$ vs. $143.5 \pm 76.5 \mathrm{mg} / \mathrm{dl}$ respectively) and Rani et $\mathrm{al}^{9}(156.1 \pm 80.4 \mathrm{mg} / \mathrm{dl}$ vs. $153.4 \pm 104.4 \mathrm{mg} / \mathrm{dl}$ respectively) also observed higher values of triglycerides in microalbuminuric subjects as compared to normoalbuminuric subjects in their studies and the difference was not significant statistically $(\mathrm{P}>0.05)$.

The subjects with microalbuminuria had lower values of LVEF compared with normoalbuminuria $(60.32 \pm 4.66 \%$ in MA, $61.17 \pm 3.60 \%$ in NA), but this difference was not statistically significant $(\mathrm{P}>0.05)$. Yildirimturk et $\mathrm{al}^{8}$ also observed lower values of LVEF in microalbuminuric diabetic subjects than in normoalbuminuric subjects in their study $(63.1 \pm 1.4 \%$ in $12 \mathrm{MA}$ patients vs. $64.4 \pm 2.3 \%$ in 38 NA patients, $\mathrm{P}>0.05$ ).

In the present study, it was found that 8 patients had some degree of left ventricular diastolic dysfunction, $3(6.38 \%)$ in NA group and 5 $(10.64 \%)$ in MA group but this difference was not significant statistically $(\mathrm{P}>0.05)$. Yildirimturk et $\mathrm{al}^{8}$ found no significant difference between microalbuminuric and normoalbuminuric subjects with regard to left ventricular diastolic function indices in their study.

The present study revealed that $6.38 \%$ patients ( 3 out of 47) in normoalbuminuric group and $34.04 \%$ patients (16 out of 47) in microalbuminuric group had silent myocardial ischemia (SMI). In normoalbuminuric group out of 3 treadmill test positive subjects, one was male and 2 were female while in microalbuminuric group out of 16 subjects, 11 were male and 5 were females. The difference was significant $(\mathrm{P}<0.01)$. Hussein and Strak $^{7}$ detected SMI in $30 \%$ microalbuminuric and $6.6 \%$ normoalbuminuric type-2 diabetic subjects in their study. Yildirimturk et $\mathrm{al}^{8}$ observed $75 \%$ microalbuminuric and $31.6 \%$ normoalbuminuric type- 2 diabetic subjects in their study. Zabeen et $\mathrm{al}^{11}$ found $42 \%$ microalbuminuric and $32 \%$ normoalbuminuric type-2 diabetic subjects had silent myocardial ischemia in their study. Rutter et $\mathrm{al}^{5}$ observed that $52 \%$ subjects ( 45 out of 86 ) had SMI. Out of these 45 , treadmill test positive patients, 28 were from microalbuminuric group and 17 were from normoalbuminuric group. Thus, all these found statistically significant difference between two groups with regard to SMI $(\mathrm{P}<0.05)$. In their follow up study, they showed that future CAD events were significantly associated with SMI $(\mathrm{P}<0.05)$ and microalbuminuria $(\mathrm{P}<0.05)$. They also observed that subjects with both SMI and MA were more likely to develop CAD events than others $(\mathrm{P}<0.01)$. In the present study it was observed that no patient had regional wall motion abnormality in both groups. 


\section{Conclusion}

Present study showed that silent myocardial ischemia was more common in microalbuminuric group as compared to normoalbuminuric group. The presence of underlying silent myocardial ischemia and microalbuminuria are significantly related to future CAD events in asymptomatic patients with type- 2 diabetes, therefore estimation of microalbuminuria in asymptomatic T2DM patients can play a good role in prediction of CAD events which can be prevented.

\section{Conflict of Interest: Nil}

\section{References}

1. Wild S, Roglic G, Green A, Sicree R, King H. Global Prevalence of Diabetes: Estimates for the year 2000 and projections for 2030. Diabetes Care. 2004 May; 27(5):1047-1053.

2. Mohan V, Sandeep S, Deepa R, Shah B, Varghese C. Epidemiology of type2 diabetes: Indian scenario. Indian $\mathrm{J}$ Med Res. 2007 Mar;125(3):217-30.

3. George I, Melpomeni P, Phivi R, Michael $\mathrm{C}$, Christos $\mathrm{P}$, Georgia $\mathrm{C}$ et al. The occurrence of microalbuminuria and retinopathy with cardiovascular risk factors; reliable predictors of asymptomatic coronary artery disease in type 2 diabetes. Hormones, 2004;3(3):198203.

4. Longo DL, Fauci AS, Kasper DL, Hauser SL, Jameson JL, Loscalzo J. Harrson's principles of internal medicine. $18^{\text {th }}$ ed. New York: Ma Graw Hill Education; 2011.

5. Rutter MK, Wahid ST, MaComb JM, Marshall SM. Significance of silent ischemia and microalbuminuria in predicting coronary events in asymptomatic patients with type 2 diabetes. J Am Col Cardiol. 2002 Jul; 40(1):56-61.
6. Satchell SC, Tooke JE. What is the mechanism of microalbuminuria in diabetes:a role for the glomerular endothelium? Diabetologia. 2008 May;51(5):714-725.

7. Hussein AZF, Strak SK. Silent myocardial ischemia and microalbuminuria in asymptomatic type- 2 diabetic patients. Pak J Med Sci. 2006;22(2):116-121.

8. Yildirimtürk $\mathrm{O}$, Kiliçgedik $\mathrm{M}$, Tuğcu A, Aytekin V, Aytekin S. The relationship of microalbuminuria with left ventricular functions and silent myocardial ischemia in asymptomatic patients with type 2 diabetes. Turk Kardiyol Dern Ars. 2009 Mar;37(2):91-7.

9. Rani PK, Raman R, Gupta A, Pal SS, Kulothungan V, Shrama T. Albuminuria and Diabetic Retinopathy in Type 2 Diabetes Mellitus Sankara Nethralaya Diabetic Retinopathy Epidemiology and Molecular Genetic Study (SN-DREAMS, report 12). Diabetol Metab Syndr. 2011,3(9):1-8.

10. Mattock MB, Barnes DJ, Viberti G, Keen $\mathrm{H}$, Burt D, Hughes JM et al. Microalbuminuria and Coronary Heart Disease in NIDDM: an incidence study. Diabetes. 1998 Nov;47(11):1786-92.

11. Zabeen S, Hoque MM, Rahman MR. Silent Myocardial Ischemia and its Association with Microalbuminuria in Type 2 Diabetes Mellitus. BSMMU J. 2012 Jan; 5(1):42-45. 